\title{
Comparative Study of Transpiration in Cooling Effect of Tree Species in the Atmosphere
}

\author{
S. K. Gupta1, Jeet Ram², Hukum Singh ${ }^{3}$ \\ ${ }^{1}$ Monitoring, Evaluation \& Audit, Uttarakhand Forest Department, Dehradun, India \\ ${ }^{2}$ Department of Forestry and Environmental Science, Kumaun University, Nainital, India \\ ${ }^{3}$ Ecology, Climate Change \& Forest Influence Division, FRI, Dehradun, India \\ Email: santoshforester86@gmail.com, jeetram2001@yahoo.com, hukumsingh97@yahoo.com
}

How to cite this paper: Gupta, S.K., Ram, J. and Singh, H. (2018) Comparative Study of Transpiration in Cooling Effect of Tree Species in the Atmosphere. Journal of Geoscience and Environment Protection, 6, 151-166. https://doi.org/10.4236/gep.2018.68011

Received: April 20, 2018

Accepted: August 26, 2018

Published: August 29, 2018

Copyright (c) 2018 by authors and Scientific Research Publishing Inc. This work is licensed under the Creative Commons Attribution International License (CC BY 4.0).

http://creativecommons.org/licenses/by/4.0/

\section{(c) (i) Open Access}

\begin{abstract}
Trees create microclimate under their crowns in comparison to the outside ambient atmosphere, which is a result of physical as well as physiological functions of the tree. The cooling produced by trees varies with species due to variation in several anatomical, structural and physiological attributes of the species. Transpiration is one of the most significant physiological functions performed by plants, which affects cooling produced by a tree under its shade. When solar energy impinges on the leaf, water emerges from its surface through transpiration taking the latent heat to convert it into water vapour. This leads to a rise in humidity of the atmosphere and reduction in temperature of the leaf. To remain leaf in equilibrium, it takes heat from the surrounding atmosphere resulting in reduction in temperature of surroundings. Since, transpiration takes place through stomata which are normally located on the ventral side of the leaf, this reduction in temperature is more experienced beneath the crown of the tree. Therefore, the present study was carried out to analyze the role of transpiration in cooling effect of five forestry tree species. The cooling produced by tree species under their shades has been found positively correlated to the transpiration rate whereas the rate of transpiration has responded positively to the ambient temperature and water conductance. However, no definite relationship has been found between frequency of open stomata and the rate of transpiration.
\end{abstract}

\section{Keywords}

Rate of Transpiration, Ambient Temperature, Cooling, Stomata, Microclimate, Water Conductance, Root Pressure

\section{Introduction}

Trees and forests are a vital component of ecology and environment. It is a 
well-known fact that forests regulate local and global temperature and influence earth's energy budget [1]. Forests influence climate chiefly by absorbing atmospheric carbon dioxide and act as carbon sink. Trees create microclimate under their crowns in comparison to the outside ambient atmosphere [2]. Factually, one usually experiences a significant coolness under the shade of trees in comparison to open sunshine, with qualitative variations. It is generally cooler under sal (Shorea robusta) tree than under teak (Tectona grandis). Similarly, it is more comfortable under a deodar (Cedrus deodara) tree as compared to that under chirpine (Pinus roxburghii) etc. (Per.obser.). The cooling generated by a tree is a result of physical as well as physiological functions of the tree. It largely depends on several physical attributes of the tree viz. size and denseness of the tree crown; size, color, roughness or smoothness and thickness of leaves in the crown; leaf water contents, equilibrium temperature of leaves, etc. which certainly affect the physiological functioning of the tree such as rate of transpiration, rate of photosynthesis, etc. The atmospheric parameters such as temperature, wind speed, relative humidity also influence the cooling generated by a tree under its shade [3] [4]. The cooling produced by trees varies with species due to variation in several anatomical, structural and physiological attributes of the species. Planting trees is commonly practiced for modulating the environment such as producing shade and cooling as well as reducing air and noise pollution [5]. Working with some tree species, they disclosed temperature reduction under shades of trees from $0.64^{\circ} \mathrm{C}$ to $2.52^{\circ} \mathrm{C}$ whereas Abdel-Aziz (2014) [6] reported cooling under tree shades from $1^{\circ} \mathrm{C}$ to $5^{\circ} \mathrm{C}$. Transpiration is one of the most significant physiological functions performed by plants, which affects cooling produced by a tree under its shade. It is important in controlling leaf temperature and significantly affects the energy budget, water potential of leaf cells and more importantly its physiological status [7]. When solar energy impinges on the leaf, water emerges from its surface through transpiration taking the latent heat to convert it into water vapor. This leads to a rise in humidity of the atmosphere and reduction in temperature of the leaf. To remain leaf in equilibrium, it takes heat from the surrounding atmosphere resulting in reduction in temperature of surroundings [8]. Since, transpiration takes place through stomata which are normally located on the ventral side of the leaf, this reduction in temperature is more experienced beneath the crowns of the trees.

Water is transported from roots to leaves through vascular tissue termed as xylem. There are several theories of transpiration such as water potential theory, vacuum theory, root pressure (also called as turgor pressure or hydrostatic pressure) theory, etc. According to water potential theory, roots have the highest water content whereas this is the lowest in leaves. On evaporation of water through stomata consuming the latent heat, water potential gradient between the leaves and other tissues of plants gets increased resulting in movement of water from roots towards the mesophyll layer of leaves. On the other hand, when water through stomata on leaves comes in contact with atmospheric heat, it evaporates 
and a vacuum is created in leaves. To fill that vacuum, water is pulled up towards leaves through capillary action in xylem. According to the root pressure theory, roots have highest turgor pressure due to highest water content whereas it is lowest in leaves owing to lowest water content. Transpiration helps in increasing the difference in turgor pressure between the leaves and other tissues of the plant resulting in movement of water towards the mesophyll of leaves [9] [10]. During the total transpiration process, the energy exchange with biosphere can be divided into three segments [11]: 1) the energy required to free the water from the soil i.e. binding energy, 2) the energy required to lift the water against gravitational force, and 3) the latent heat of evaporization.

The climate is changing and changing more rapidly. The present rate of warming of atmosphere is reported to be $0.2^{\circ} \mathrm{C}$ to $0.5^{\circ} \mathrm{C}$ per decade [12]. The problem is being further aggravated due to rapid industrialization, reckless cutting of trees, and other anthropogenic activities, which has alarmed the sensitive segment of the society to take initiatives towards mitigation of global warming. The more appropriate way, besides use of alternative means of energy, is to check reckless deforestation and promote ecologically more valuable species in afforestation and reforestation programmes. To encourage research on identification of ecologically more valuable species is of utmost importance to face the present challenges of global warming. Obviously, the transpiration plays a significant role in producing cooling by trees under their shades. Therefore, an endeavour has been made with the aim to study the role of transpiration in producing cooling comparatively under shades of five forestry tree species.

\section{Material and Methods}

Physiographic Characteristics of the Study Area: Five isolated sample trees, belonging to different categories, namely Kadam (Anthocephalus chinensis L.), Benjamin fig. (Ficus benjamina L.), Dhauri (Lagerstroemia floribunda L.), Mango (Mangifera indica L.), and Yellow Goldmohur (Peltophorum africanumL.) were selected in the premises of Forest Research Institute, Dehradun, India. Because, isolated trees were required for the study and isolated trees of the sample species were not available in numbers in the premises of the study area, single trees with more number of measurements adopted for replications. The sample trees were disease free, physiologically active, having regular and vigorous crowns. The study area lies between $30^{\circ} 19^{\prime} 55^{\prime \prime}$ and $30^{\circ} 19^{\prime} 16^{\prime \prime}$ North latitude and $77^{\circ} 58^{\prime} 40^{\prime \prime}$ to $78^{\circ} 1^{\prime}$ East longitude at an elevation of $640 \mathrm{~m}$ above mean sea level [13]. It is almost plane with gentle slope towards south-west direction. There exists a micro-climate due to presence of great deal of vegetal cover. Heavy rains occur during monsoon which breaks at the end of June and continues up to the last of September. Maximum rainfall is received in the months of July-August [14]. Besides, showers are quite often for the entire year in the region. Frost happens during winter season especially in the months of January-February. Generally, winds of moderate velocity prevail from western direc- 
tion. The minimum and maximum temperatures exhibit wide variations, extreme cold exist between mid-December to February whereas hot conditions persist in the months of May-June. The area covers originally natural forest of Shorearobusta L. and associates, heavily infested with Lantana camara L. along with scattered patches of Cedrella toona L., Dalbergia sissoo L. and gregarious growth of Bamboo. Tree plantations mainly of Dendrocalamus strictus L., Tactona grandis L., Pinus roxburghii L. and Eucalyptus etc. species were raised in different years for experimental, demonstration and esthetic purposes along with Arboretum, Bamboo setum, Botanical garden and training. Here, sizes and vigour of tree crowns are more important than diameter or age of trees for the present study, which are species dependent characteristics. Therefore, average sized trees were selected as sample trees.

Determination of Cooling under Tree Shades: In order to determine the local cooling effect i.e. difference between temperatures in sunshine or the ambient atmospheric temperature and temperature under the shade of the sample tree, it was very important to decide at which height above the ground the temperatures in the sunshine as well as under the shades of crowns of trees be measured. During the day, when insolation impinges on tree canopy, a part of it is absorbed by the canopy increasing the air and leaf temperatures within the canopy and the other part reaches the ground penetrating through the canopy, which increases the temperature of soil surface. As the soil surface warms, it not only conducts heat deeper into the soil but also radiates into the air augmenting the air temperature above the ground surface. Thus, the air temperature at $1.5 \mathrm{~m}$ above the ground is affected utmost by the radiation reaching up to that level [15] [16] [17]. Lin \& Lin (2010) [5] also chose $1.5 \mathrm{~m}$ above the ground as reference point to compare temperatures in the sun and inside the shade of tree canopies in their study. Therefore, in the present study, it was decided to measure temperatures at a $1.5 \mathrm{~m}$ above the ground in the sunshine as well as under tree shades of the sample trees. The Thermo Anemometer, AN 200, Extech was utilized for making the measurements of temperatures, which gives temperature and wind speed simultaneously.

The measurements of temperatures were made in the afternoon between 12.00 noon to $2.00 \mathrm{PM}$, twice every month after a gap of 15 days, on fair weather day. Temperatures were recorded under mild wind speed conditions, either at same wind speed or at a variation range of not more than $1 \mathrm{~km} / \mathrm{hr}$ and on saturation for a time of not less than 10 seconds. The measurements were made from October 2015 to June 2016. But, in case of deciduous tree species viz. L. floribunda and $P$. africanum, measurement were considered only in crown bearing condition with physiological parameters of the trees. Thus, data regarding ambient temperatures, temperatures under shades of the sample trees, cooling produced by the respective trees were analyzed.

Determination of Physiological Parameters: Portable Photosynthesis System (6400-XT, LI-COR, Lincon, NE) was employed to determine the rate of 
transpiration and $\mathrm{H}_{2} \mathrm{O}$ conductance of the sample trees. The rate of photosynthesis is usually minimum right before sunrise and gradually increases to reach maximum right before noon and falls continuously up to minimum right after sunset [18] [19]. The measurements were, therefore, made between $10 \mathrm{AM}$ to 12 noon under clear sky conditions in the third quarter of every month from October 2015 to June 2016. July to September period was excluded from the study being rainy season and cloudy weather in the area. The instrument was taken near the leaves of crowns of the sample trees and a leaf was put into the leaf chamber and the values of the parameters were recorded when stabilized. A ladder of 15' height was used for this purpose. This exercise was repeated at least on 10 different leaves covering larger portion, from top to bottom, of crown in different but sunny directions only. Thus, the average values of all the measurements in respect to the rate of transpiration and $\mathrm{H}_{2} \mathrm{O}$ conductance were taken into consideration for analysis.

Determination of Leaf Water Content: The leaf water content of the every sample tree species was determined by randomly taken out three healthy leaves each from outer, middle and inner crowns, of different sizes, from every sample tree. These leaves were weighed one by one with the help of an electronic weighing balance to obtain fresh weight, after cleaning and drying them and put in separate envelopes and placed in an oven at $80^{\circ} \mathrm{C}$, for at least 48 hours. Dry weight of every leaf was also recorded and water content was obtained by subtracting dried weight from the fresh weight. The Arcsin statistical method has been employed to determine the average dry weight per cent and water content per cent as well as Standard Error of mean (SEM) for all the leaves of different sample trees. The average water content in per cent has been obtained on the basis of the fresh weight.

Determination of Frequency of Open Stomata on Leaves: Nail varnish method as described by [20] was employed in the month of November to determine stomatal density on the leaves of all the sample trees for peeling off. This exercise was performed between 10.00-11.00 A.M. on a clear sky day in the month of November. The slides were examined on an Eclipse Microscope, 50i, Nikon, 40 xresolution, attached to a computer and photo prints taken on the computer. Two photo prints at different places on every slide were taken. Number of open stomata were counted on these photo prints in an area of $500 \mu \mathrm{m} \times$ $500 \mu \mathrm{m}$ and computed for the per centimeter square area of leaf.

\section{Results}

There witnessed variation in cooling effect of the sample tree species in respect to different months as well as change in species. $M$. indica showed the highest cooling effect of all the sample tree species and varied from 2.8 to 5.9 (average $3.9 \pm 0.96)^{\circ} \mathrm{C}$ followed by $F$. benjamina 2.5 to 5.6 (average $\left.3.7 \pm 1.01\right)^{\circ} \mathrm{C}$, A. chinensis 1.3 to 5.1 (average $2.8 \pm 1.17$ ) ${ }^{\circ} \mathrm{C}, P$. africanum 2.6 to 5.1 (average $3.5 \pm$ 
$1.00)^{\circ} \mathrm{C}$ and $L$. floribunda 1.3 to 3.6 (average $\left.2.5 \pm 0.96\right)^{\circ} \mathrm{C}$, the lowest, during the present study period and given in Table 1.

The rates of transpiration of all the sample trees as presented in Table 2 exhibited great variations in respect of their values for different tree species as well as in different months. It has come out that, generally, $P$. africanum has illustrated the highest rate of transpiration varying between $6.55 \pm 1.90$ to $1.75 \pm 0.47$ (average 4.37) $\mathrm{mmol} \mathrm{H}_{2} \mathrm{O} \mathrm{m} \mathrm{m}^{-2} \cdot \mathrm{s}^{-1}$ followed by $A$. chinensis $7.08 \pm 2.31$ to $0.85 \pm 0.32$ (average 3.16), F. benjamina $5.09 \pm 1.07$ to $0.56 \pm 0.29$ (average 2.71), $M$. indica $4.59 \pm 0.53$ to $0.53 \pm 0.35$ (average 2.44) whereas L. floribunda $1.92 \pm 1.21$ to 0.70 \pm 0.12 (average 1.42) has shown the least rate of transpiration, of all the sample tree species. Similarly, the values of water conductance varied between $(0.74 \pm$

Table 1. Species wise temperatures, cooling and analytical parameters in different months.

\begin{tabular}{|c|c|c|c|c|c|c|c|c|c|c|c|}
\hline \multirow{2}{*}{ S No } & \multirow{2}{*}{ Name of Species } & \multirow{2}{*}{ Particulars } & \multicolumn{9}{|c|}{ Name of Months } \\
\hline & & & Oct. -15 & Nov. -15 & Dec. 15 & Jan.-16 & Feb.-16 & Mar.-16 & Apr.-16 & May-16 & Jun.-16 \\
\hline \multirow{5}{*}{1} & \multirow{5}{*}{ M. indica L. } & Ambient Temp $\left({ }^{\circ} \mathrm{C}\right)$ & 34.9 & 29.5 & 27.1 & 22.9 & 27.6 & 33.8 & 36.0 & 38.2 & 37.2 \\
\hline & & Temp under Shade $\left({ }^{\circ} \mathrm{C}\right)$ & 29.0 & 25.0 & 23.0 & 20.1 & 23.8 & 31.0 & 32.8 & 34.0 & 33.2 \\
\hline & & Cooling $\left({ }^{\circ} \mathrm{C}\right)$ & 5.9 & 4.5 & 4.1 & 2.8 & 3.8 & 2.8 & 3.2 & 4.2 & 4.0 \\
\hline & & Pearson Correlation & 0.98 & 0.86 & 0.27 & 0.92 & 0.22 & 0.71 & 0.79 & 0.89 & 0.84 \\
\hline & & SEM & 0.30 & 0.16 & 0.47 & 0.43 & 0.20 & 0.17 & 0.22 & 0.28 & 0.25 \\
\hline \multirow{5}{*}{2} & \multirow{5}{*}{ F. benjamina L. } & Ambient Temp $\left({ }^{\circ} \mathrm{C}\right)$ & 33.3 & 29.9 & 26.5 & 22.5 & 27.8 & 33.6 & 36.1 & 38.6 & 38.3 \\
\hline & & Temp under Shade $\left({ }^{\circ} \mathrm{C}\right)$ & 27.7 & 25.8 & 22.7 & 20.0 & 24.3 & 31.1 & 33.4 & 35.0 & 33.8 \\
\hline & & Cooling $\left({ }^{\circ} \mathrm{C}\right)$ & 5.6 & 4.1 & 3.8 & 2.5 & 3.5 & 2.5 & 2.7 & 3.6 & 4.5 \\
\hline & & Pearson Correlation & 0.38 & 0.88 & 0.09 & 0.94 & 0.51 & 0.55 & 0.62 & 0.98 & 0.58 \\
\hline & & SEM & 0.70 & 0.28 & 0.38 & 0.23 & 0.23 & 0.10 & 0.17 & 0.27 & 0.13 \\
\hline \multirow{5}{*}{3} & \multirow{5}{*}{ A. chinensis $\mathrm{L}$. } & Ambient Temp $\left({ }^{\circ} \mathrm{C}\right)$ & 34.8 & 29.8 & 24.2 & 22.1 & 30.6 & 30.9 & 36.8 & 37.6 & 36.4 \\
\hline & & Temp under Shade $\left({ }^{\circ} \mathrm{C}\right)$ & 29.7 & 26.0 & 21.7 & 20.2 & 27.5 & 29.6 & 35.1 & 34.8 & 33.1 \\
\hline & & Cooling $\left({ }^{\circ} \mathrm{C}\right)$ & 5.1 & 3.8 & 2.5 & 1.9 & 3.1 & 1.3 & 1.7 & 2.8 & 3.3 \\
\hline & & Pearson Correlation & 0.95 & 0.72 & 0.18 & 0.67 & 0.88 & 0.11 & 0.98 & 0.54 & 0.58 \\
\hline & & SEM & 0.37 & 0.30 & 0.08 & 0.26 & 0.20 & 0.07 & 0.31 & 0.07 & 0.08 \\
\hline \multirow{4}{*}{4} & \multirow{4}{*}{$P$. africanum $\mathrm{L}$. } & Ambient Temp $\left({ }^{\circ} \mathrm{C}\right)$ & 34.0 & 29.4 & 25.8 & - & - & - & 34.6 & 37.6 & 37.2 \\
\hline & & Temp under Shade $\left({ }^{\circ} \mathrm{C}\right)$ & 28.9 & 25.8 & 22.5 & - & - & - & 32.0 & 34.3 & 33.5 \\
\hline & & Pearson Correlation & 0.34 & 0.90 & 0.75 & - & - & - & 0.82 & 0.98 & 0.93 \\
\hline & & SEM & 0.23 & 0.14 & 0.53 & - & - & - & 0.11 & 0.41 & 0.22 \\
\hline \multirow{5}{*}{5} & \multirow{5}{*}{ L. floribunda L. } & Ambient Temp $\left({ }^{\circ} \mathrm{C}\right)$ & 32.7 & 30.6 & 24.7 & 22.6 & 27.7 & 31.6 & - & - & - \\
\hline & & Temp under Shade $\left({ }^{\circ} \mathrm{C}\right)$ & 29.1 & 27.2 & 22.2 & 20.7 & 25.2 & 30.3 & - & - & - \\
\hline & & Cooling $\left({ }^{\circ} \mathrm{C}\right)$ & 3.6 & 3.4 & 2.5 & 1.9 & 2.5 & 1.3 & - & - & - \\
\hline & & Pearson Correlation & 0.53 & 0.97 & 0.90 & 0.99 & 0.20 & 0.71 & - & - & - \\
\hline & & SEM & 0.10 & 0.36 & 0.18 & 0.41 & 0.18 & 0.19 & - & - & - \\
\hline
\end{tabular}


Table 2. Rate of transpiration and water conductance of sample tree species.

\begin{tabular}{|c|c|c|c|c|}
\hline \multirow{2}{*}{ S No } & \multirow{2}{*}{ Name of Months } & \multirow{2}{*}{ Name of Species } & Rate of Transpiration $(\mathrm{T})$ & \multirow{2}{*}{$\begin{array}{c}\text { Water Conductance } \\
\mathrm{mol} \mathrm{H}_{2} \mathrm{O} \mathrm{m}^{-2} \cdot \mathrm{s}^{-1}\end{array}$} \\
\hline & & & $\mathrm{mmol} \mathrm{H} \mathrm{H}_{2} \mathrm{O} \mathrm{m}^{-2} \cdot \mathrm{s}^{-1}$ & \\
\hline \multirow{5}{*}{1} & \multirow{5}{*}{ October 15} & M. indica $\mathrm{L}$. & $4.59 \pm 0.53$ & $0.24 \pm 0.06$ \\
\hline & & F. benjamina $\mathrm{L}$. & $5.09 \pm 1.07$ & $0.20 \pm 0.04$ \\
\hline & & A. chinensis $\mathrm{L}$. & $4.68 \pm 1.00$ & $0.31 \pm 0.01$ \\
\hline & & L. floribunda L. & $1.92 \pm 1.21$ & $0.05 \pm 0.04$ \\
\hline & & $P$. africanum $\mathrm{L}$. & $6.55 \pm 1.90$ & $0.34 \pm 0.26$ \\
\hline \multirow{5}{*}{2} & \multirow{5}{*}{ November 15} & M. indica $\mathrm{L}$. & $3.02 \pm 0.02$ & $0.20 \pm 0.02$ \\
\hline & & F. benjamina $\mathrm{L}$. & $1.56 \pm 0.73$ & $0.09 \pm 0.04$ \\
\hline & & A. chinensis $\mathrm{L}$. & $3.05 \pm 0.51$ & $0.41 \pm 0.18$ \\
\hline & & L. floribunda L. & $1.63 \pm 0.67$ & $0.08 \pm 0.04$ \\
\hline & & $P$. africanum $\mathrm{L}$. & $3.74 \pm 1.25$ & $0.22 \pm .08$ \\
\hline \multirow{5}{*}{3} & \multirow{5}{*}{ December 15} & M. indica L. & $0.71 \pm 0.39$ & $0.08 \pm 0.06$ \\
\hline & & F. benjamina $\mathrm{L}$. & $0.56 \pm 0.29$ & $0.04 \pm 0.02$ \\
\hline & & A. chinensis $\mathrm{L}$. & $1.01 \pm 0.40$ & $0.08 \pm 0.04$ \\
\hline & & L. floribunda $\mathrm{L}$. & $0.70 \pm 0.12$ & $0.04 \pm 0.01$ \\
\hline & & $P$. africanum $\mathrm{L}$. & $1.75 \pm 0.47$ & $0.15 \pm 0.05$ \\
\hline \multirow{5}{*}{4} & \multirow{5}{*}{ January 16} & M. indica L. & $2.15 \pm 0.39$ & $0.13 \pm 0.03$ \\
\hline & & F. benjaminaL. & $3.27 \pm 0.51$ & $0.18 \pm 0.03$ \\
\hline & & A. chinensis $\mathrm{L}$. & $3.25 \pm 0.36$ & $0.20 \pm 0.02$ \\
\hline & & L. floribunda L. & $1.69 \pm 0.09$ & $0.07 \pm 0.01$ \\
\hline & & $P$. africanum $\mathrm{L}$. & - & - \\
\hline \multirow{5}{*}{5} & \multirow{5}{*}{ February 16} & M. indica $\mathrm{L}$. & $0.53 \pm 0.35$ & $0.04 \pm 0.03$ \\
\hline & & F. benjamina L. & $2.07 \pm 0.67$ & $0.13 \pm 0.05$ \\
\hline & & A. chinensis $\mathrm{L}$. & $1.45 \pm 0.51$ & $0.07 \pm 0.02$ \\
\hline & & L. floribunda L. & $0.88 \pm 0.47$ & $0.04 \pm 0.02$ \\
\hline & & P. africanum $\mathrm{L}$. & - & - \\
\hline \multirow{5}{*}{6} & \multirow{5}{*}{ March 16} & M. indica L. & $0.88 \pm 0.57$ & $0.05 \pm 0.05$ \\
\hline & & F. benjaminaL. & $1.12 \pm 0.69$ & $0.10 \pm 0.06$ \\
\hline & & A. chinensis $\mathrm{L}$. & $0.85 \pm 0.32$ & $0.03 \pm 0.02$ \\
\hline & & L. floribunda L. & $1.69 \pm 0.40$ & $0.20 \pm 0.03$ \\
\hline & & P. africanum $\mathrm{L}$. & - & - \\
\hline \multirow{5}{*}{7} & \multirow{5}{*}{ April 16} & M. indica L. & $2.15 \pm 0.83$ & $0.04 \pm 0.02$ \\
\hline & & F. benjamina L. & $1.43 \pm 0.29$ & $0.03 \pm 0.01$ \\
\hline & & A. chinensis $\mathrm{L}$. & $4.52 \pm 0.81$ & $0.11 \pm 0.02$ \\
\hline & & L. floribunda L. & - & - \\
\hline & & $P$. africanum $\mathrm{L}$. & $2.69 \pm 0.76$ & $0.04 \pm 0.02$ \\
\hline
\end{tabular}




\section{Continued}

\begin{tabular}{|c|c|c|c|c|}
\hline & & M. indica L. & $3.96 \pm 0.77$ & $0.09 \pm 0.03$ \\
\hline & & F. benjamina L. & $4.58 \pm 1.39$ & $0.10 \pm 0.03$ \\
\hline \multirow[t]{5}{*}{8} & May 16 & A. chinensis $\mathrm{L}$. & $2.54 \pm 2.57$ & $0.06 \pm 0.07$ \\
\hline & & L. floribunda L. & - & - \\
\hline & & $P$. africanum $\mathrm{L}$. & $6.29 \pm 1.24$ & $0.16 \pm 0.05$ \\
\hline & & M. indica L. & $3.96 \pm 0.74$ & $0.24 \pm 0.08$ \\
\hline & & F. benjamina L. & $4.72 \pm 0.78$ & $0.24 \pm 0.04$ \\
\hline \multirow[t]{3}{*}{9} & June 16 & A. chinensis $\mathrm{L}$. & $7.08 \pm 2.31$ & $0.49 \pm 0.07$ \\
\hline & & L. floribunda L. & - & - \\
\hline & & $P$. africanum $\mathrm{L}$. & $5.22 \pm 0.70$ & $0.74 \pm 0.36$ \\
\hline
\end{tabular}

0.36 to $\left.0.04 \pm 0.02 \mathrm{~mol} \mathrm{H}_{2} \mathrm{O} \mathrm{m} \mathrm{m}^{-2} \cdot \mathrm{s}^{-1}\right)$ for $P$. africanum, $(0.24 \pm 0.04$ to $0.03 \pm 0.01)$ for $F$. benjamina, $(0.49 \pm 0.07$ to $0.03 \pm 0.02)$ for $A$. chinensis, $(0.24 \pm 0.08$ to $0.04 \pm 0.03)$ for $M$. indica, and $(0.20 \pm 0.03$ to $0.04 \pm 0.02)$ for $L$. floribunda as depicted in Table 2.

The cooling produced by the selected tree species under their shades have been found positively correlated to their transpirational rates as shown in Figure 1 whereas rate of transpiration has responded positively to the ambient temperature and water conductance for all the sample tree species as illustrated in Figure 2 and Figure 3.

A. chinensis has the highest leaf water content followed by $F$. benjamina, $L$. floribunda, $M$. indicaand $P$. africanum as shown in Table 3. Moreover, no definite relationship has been found between frequency of open stomata and the rate of transpiration.

\section{Discussion}

Evidently, there has been obtained an explicit variation in cooling produced by the respective sample tree species which is certainly related to difference in size and denseness of their crowns as well as other physical attributes of leaves present in the crowns of trees along with their physiological behaviour. It is the tree crown which obstructs the flow of solar energy and exhibits physiological performance, which produces cooling under the canopy. The results of the study are in harmony with results obtained by [6] but have disparity with [5]. This disparity in temperature reduction might have certainly been due to the locality factors of the respective study areas along with change in species resulting in variation in physical and physiological attributes of the tree species selected for studies.

The rates of transpiration of all the sample trees as presented in Table 2 exhibited great variations in respect of their values for different tree species as well as in different months. Their values decreased from October 2015 towards winter 


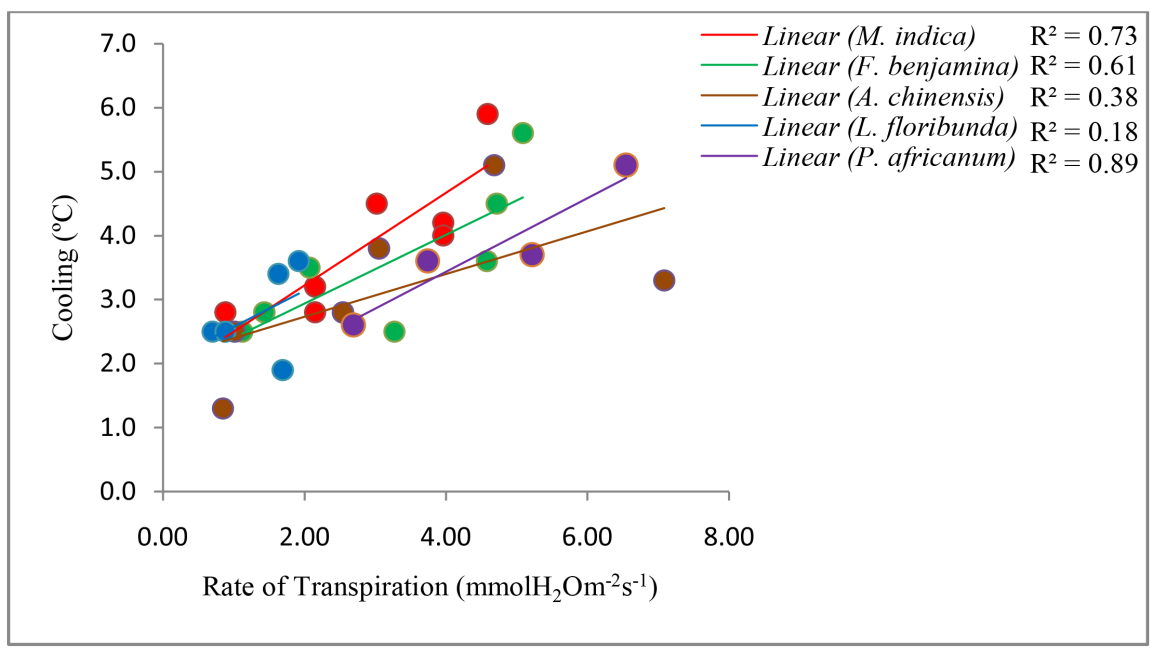

Figure 1. Correlation between rate of transpiration and cooling.

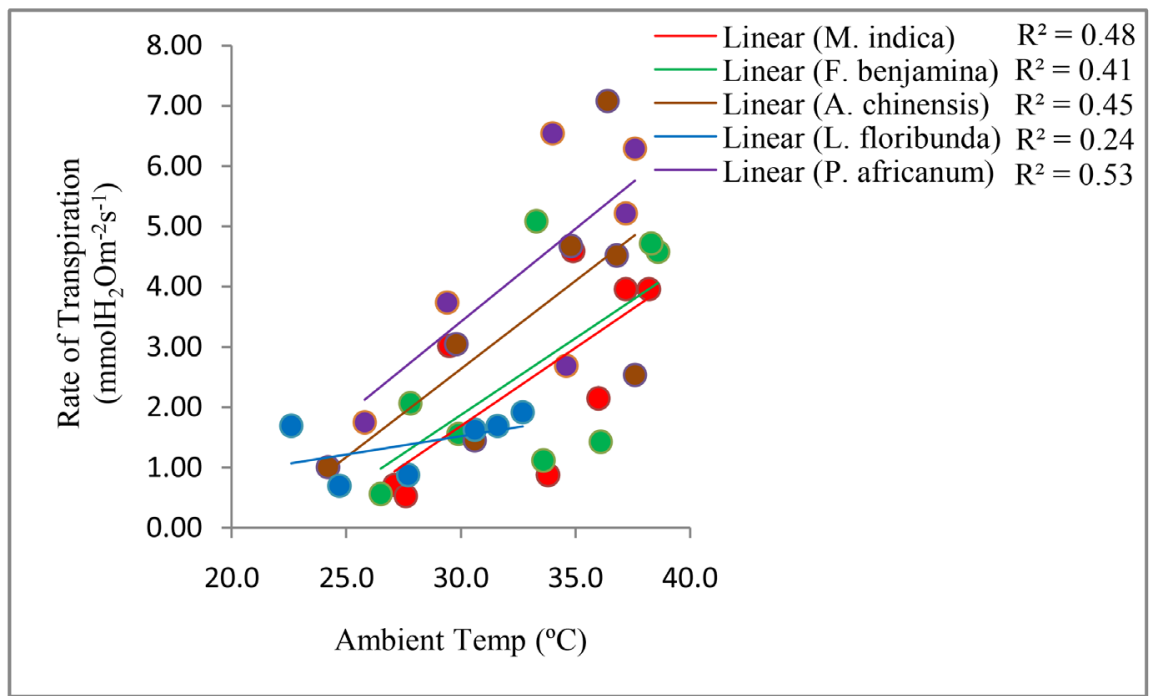

Figure 2. Correlation between ambient temperature and rate of transpiration.

season and increased from April 2016 onwards except an increase in January 2016 which might have been due to more water availability in the soil on account of vagary of weather. However, the behavior shown by L. floribunda in March 2016 had been peculiar, which needs further investigation. Similarly, water conductance for all the sample tree species also showed variation during the study period. The variation in rates of transpiration and water conductance of different species in different months were certainly related to changes in structural and anatomical factors of leaves of different species along with variation in the time of different life stages of leaves viz. developmental stage, senescence and abscission. P. africanum exhibited drastic leaf shedding in January 2016 and the tree became leafless by the end of the month followed by emergence of new leaves in April 2016. On the other hand, L. floribunda started to shed its leaves in February 2016 but the tree became crownless in April and new leaves emerged 


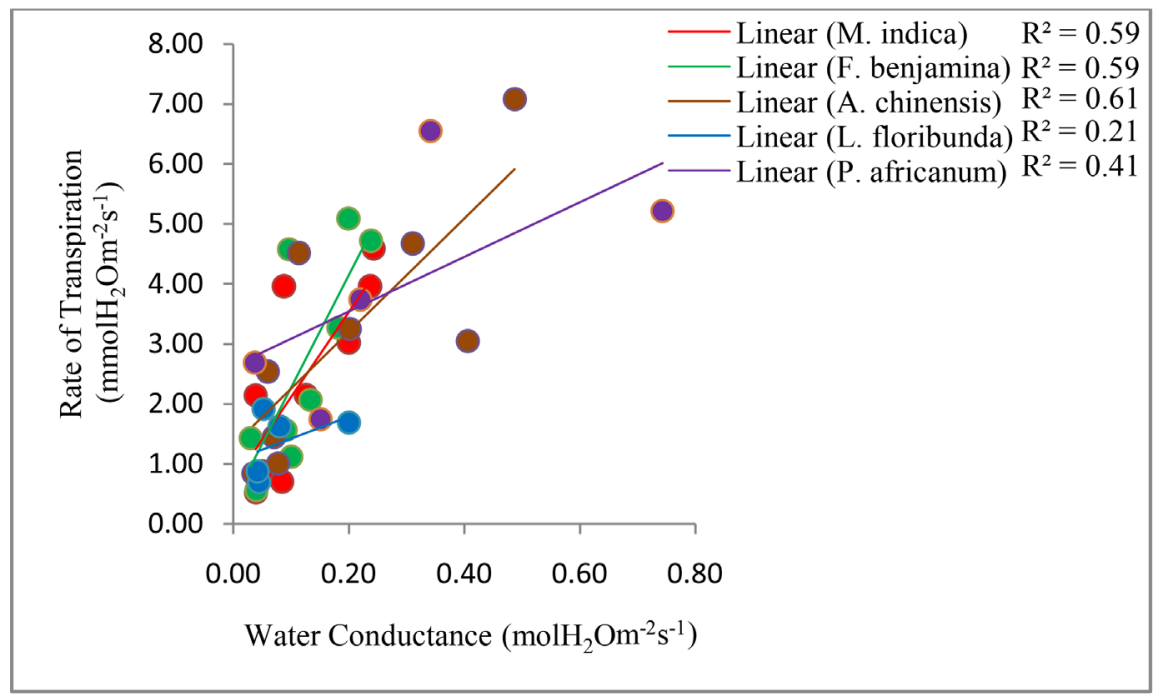

Figure 3. Correlation between water conductance and rate of transpiration.

Table 3. Dry weight and water contents of leaves of the sample trees.

\begin{tabular}{|c|c|c|c|c|c|c|c|c|}
\hline \multirow{2}{*}{$\begin{array}{l}\text { S. } \\
\text { No. }\end{array}$} & \multirow{2}{*}{ Name of Species } & \multirow{2}{*}{$\begin{array}{c}\text { Total } \\
\text { No. of } \\
\text { Leaves }\end{array}$} & \multirow{2}{*}{$\begin{array}{c}\text { Total } \\
\text { Fresh } \\
\text { Weight } \\
(\mathrm{gm})\end{array}$} & \multicolumn{2}{|c|}{ Dry Weight Content } & \multicolumn{2}{|c|}{ Water Content } & \multirow[b]{2}{*}{ SEM } \\
\hline & & & & $\begin{array}{l}\text { Total } \\
(\mathrm{mg})\end{array}$ & $\%$ & $\begin{array}{l}\text { Total } \\
\text { (gm) }\end{array}$ & $\%$ & \\
\hline 1 & M. indica $\mathrm{L}$. & 9 & 27.18 & 12.15 & 44.70 & 15.03 & 55.30 & 0.08 \\
\hline 2 & F. benjamina L. & 9 & 8.98 & 3.67 & 40.87 & 5.31 & 59.13 & 0.08 \\
\hline 3 & A. chinensis $\mathrm{L}$. & 9 & 27.04 & 10.34 & 38.24 & 16.70 & 61.76 & 0.01 \\
\hline 4 & L. floribunda L. & 9 & 15.86 & 7.03 & 44.33 & 8.83 & 55.67 & 0.06 \\
\hline 5 & $P$. africanum $\mathrm{L}$. & 9 & 9.61 & 5.20 & 54.11 & 4.41 & 45.89 & 0.02 \\
\hline
\end{tabular}

in June. A. chinensis commenced leaf shedding in March 2016 and continued till the month of April along with simultaneous sprouting of new leaves. However, $M$. indica and F. benjamina showed normal leaf shedding from April to June 2016 and leaves were renewed during the entire year due to their evergreen nature. Arrangement of stomata on leaf epidermis also influences leaf functions related to transpiration and photosynthesis. Enormous diversity in size, density, distribution of stomata exists among various tree species, which might have also affected their rates of transpiration. Generally, stomata are randomly scattered on broad leaves of dicotyledons whereas they occur in parallel rows to the leaf axis in narrow elongated leaves of monocotyledons and conifers [21] [22]. Stomata may be located above (raised stomata) or below (sunken stomata) or at the same level of other cells in the leaf epidermis. Some may also occur in depressions called "stomatal crypts". Sunken stomata lead to decreased transpiration whereas the raised stomata result in higher transpiration losses. Moreover, the presence of trichomes on the leaf surfaces reduces transpiration losses, besides of course the presence and thickness of cuticle and rolling over of the leaves [23].

The rate of transpiration is controlled by several factors of environment as 
well as anatomical structure of leaves such as atmospheric temperature, water availability in the soil, water content of leaves, water conductance, etc. Increase in ambient temperature augments the rate of transpiration whereas high humidity produces resistance to it. Wind speed significantly affects the rate of transpiration which also depends upon the radiation load on the leaf. At higher radiation load, an increase in wind speed decreases the rate of transpiration whereas at lower radiation load, transpirational rate increases with wind speed. In still atmospheric conditions, water loss due to transpiration can accumulate in the form of vapor close to the leaf surface termed as boundary layer which resists movement of water from the leaves and reduces the rate of transpiration. However, at fairly intermediate radiation load on leaf, the rate of transpiration is relatively unaffected by wind speed [8]. Moreover, rough leaves provide larger surface area and more number of stomata resulting in higher rate of transpiration and photosynthesis, which facilitates more cooling advantage due to high humidity surrounding the crown [5]. It could be easily recognized by rubbing the leaves with hands that leaves of $F$. benjamina were smoothest of all the sample trees followed by $A$. chinensis, L. floribunda, $P$. africanum and $M$. indica. The smoothness or roughness of leaves of different sample trees was differentiated with the help of senior Botanists.

Generally, it is presumed that more content of water in leaves will result in higher rate of transpiration. But, the results of the present study do not support this presumption. Evidently, A. chinensis has the highest leaf water content followed by $F$. benjamina, L. floribunda, $M$. indicaand $P$. africanum whereas highest rate of transpiration has been exhibited by $P$. africanum followed by $A$. chinensis, F. benjamina, $M$. indica and $L$. floribunda, which might have been due to the reasons that other factors affecting rate of transpiration also play their role accordingly. Factually, Terrestrial plants face the contradictory demand of maximizing carbon dioxide uptake for photosynthesis while minimizing water loss to the atmosphere [24].

Correlation between the cooling produced by different trees under their shades and the rates of transpiration were studied and the results have been depicted in Figure 1, which have come out positive for all the sample trees with $A$. chinensis $\left(R^{2}=0.38, p=0.07\right), F$. benjamina $\left(R^{2}=0.61, p=0.04\right)$, L. floribunda $\left(R^{2}=0.18, p=0.13\right), M$. indica $\left(R^{2}=0.73, p=0.04\right)$ and $P$. africanum $\left(R^{2}=0.89\right.$, $p=0.23)$, at $95 \%$ level of confidence $(p=0.05)$. Evidently, correlation is very high and significant in $M$. indica, high and significant in $F$. benjamina, very high but not significant in $P$. africanum, high but not significant in $A$. chinensis whereas very low and not significant in $L$. floribunda. This variation might have been related to variation in certain anatomical parameters of leaves of different species. When the solar energy impinges on the leaf, water emerges from its surface through transpiration taking the latent heat to convert it into water vapour. This leads to a rise in humidity of the atmosphere and reduction in temperature of the leaf. To remain leaf in equilibrium, it takes heat from the 
surrounding atmosphere resulting in reduction in temperature of surroundings [8]. Water molecules are capable of holding great deal of energy without releasing it as heat. In the vapour form, water molecules absorb larger amount of energy in the form of latent heat from objects coming in contact including trees, ground and human body [10]. Since, transpiration takes place through stomata which are normally located on the ventral side of the leaf, this reduction in temperature is more experienced beneath the crown of the tree. Thus, more transpiration by tree crown implies more reduction in air temperature inside the shade of the crown and consequently more cooling is produced by tree crown.

Here, it is also significant that though cooling generated by tree under its crown was positively correlated to the rate of transpiration for every sample tree species yet no similarity was found between the rate of transpiration and cooling produced by them among different species. Evidently, $P$. africanum had the highest average rate of transpiration but not the cooling produced by it. Similarly, M. indica had the highest cooling effect but not the rate of transpiration. This might have happened because the cooling produced by tree under its crown is not only a function of rate of transpiration but size and vigour of tree crown prominently affects its cooling performance. It is the crown of tree which absorbs, scatters and reflects the incoming solar radiation resulting in reduction in the amount of solar energy penetrating through the canopy. The amount of solar radiation absorbed by a tree depends on its leaf area index. Denser canopies, with higher LAI, can check even up to $95 \%$ of the visible spectrum falling on it making the air beneath the canopy cooler [25]. The leaf area index of tree varies with change in species.

The effect of atmospheric temperature on the rate of transpiration was also studied for the sample trees and ambient temperature has responded positively to rate of transpiration for all the sample tree species as depicted in Figure 2 with $A$. chinensis $\left(R^{2}=0.45, p=0.18\right), F$. benjamina $\left(R^{2}=0.41, p=0.22\right), L$. floribunda $\left(R^{2}=0.24, p=0.86\right), M$. indica $\left(R^{2}=0.48, p=0.0 .15\right)$ and $P$. africanum $\left(R^{2}=0.53, p=0.30\right)$. Other workers [26] [27] [28] also disclosed positive association between rate of transpiration and atmospheric temperature and the result of the present study are in harmony with their results. Water coming out of stomata is converted into water vapour taking the latent heat resulting in reduction in leaf temperature. The atmospheric temperature is one of the most prominent factors that incite transpiration in leaves. High atmospheric temperature responds to large amount of water loss through transpiration. The temperature of leaf is modified by transpirational cooling due to consumption of latent heat of evaporation. Water vapour density inside the leaf is a function of leaf temperature, alike the latent heat of water. Latent heat, however, is not a strong function of temperature over the normal temperature range [29]. The correlation between rate of transpiration and water conductance was also studied and the results have been illustrated in Figure 3. The correlation was found positive for all the sample trees with $A$. chinensis $\left(R^{2}=0.61, p=0.11\right), F$. benjamina $\left(R^{2}=\right.$ 
$0.59, p=0.64)$, L. floribunda $\left(R^{2}=0.21, p=0.09\right), M$. indica $\left(R^{2}=0.59, p=0.32\right)$ and $P$. africanum $\left(R^{2}=0.41, p=0.12\right)$.

Living leaves transpire moisture through stomata. Water vapour escapes by diffusion through stomata and across the boundary layer to the free air beyond the leaf [30]. However, this diffusion of water vapour feels resistance due to presence of tiny hairs in the stomata, which is called stomatal resistance. Also, the air present across the leaf mesophyll exerts pressure against escape of water vapour, which is termed as boundary layer resistance. These two together denote the total diffusion resistance of the pathway. Leaves of different species have different diffusion resistance and therefore different rates of transpiration due to their varying anatomical and structural properties. When stomata are completely open during sunshine, the internal resistance is minimal. More water availability in the soil increases the rate of transpiration. When water is scarce and the temperature is high, plants can quickly dry out and die. Some plants, therefore, have specific adaptations that enable them to help control water loss [31] [32]. Due to lesser molecular weight of water than $\mathrm{CO}_{2}$, water diffuses more readily than $\mathrm{CO}_{2}$ [8].

Number of open stomate is effectively responsible for physiological activities of leaves such as photosynthesis, transpiration, water conductance, $\mathrm{CO}_{2}$ conductance etc. [23]. The data in respect to frequency of open stomata and physiological parameters presented in Table 4 ascertains, more or less, positive association between number of open stomata and $\mathrm{H}_{2} \mathrm{O}$ conductance. Here, the data in the month of November has been selected for analysis because the frequency of open stomata was determined in November. However, there was not been found a definite correlation between the number of open stomata and the rate of transpiration. This might have been because of the reason that the root pressure, also called hydrostatic pressure, also plays prominent role in transpiration by plants. The increased root pressure gradient between leaves and other tissues of the plant on evaporation of water through stomata results in pushing up of water from roots towards the mesophyll of leaves. Conclusively, the root pressure is more significant in controlling the rate of transpiration than the number of open stomata. In case of guttation also, root pressure is the prime cause of impetus for pushing up of water from roots towards leaves and coming out of leaves through hydathodes [33].

Table 4. Frequency of open stomata, rate of transpiration and $\mathrm{H}_{2} \mathrm{O}$ conductance of Sample Trees in the month of November.

\begin{tabular}{|c|c|c|c|c|c|c|}
\hline \multirow{2}{*}{ S No } & \multirow{2}{*}{ Parameters } & \multicolumn{5}{|c|}{ Name of Species } \\
\hline & & A. chinensis & F. benjamina & L. floribunda & M. indica & P. africanum \\
\hline 1 & $\begin{array}{l}\text { Frequency of Open } \\
\text { Stomata }\left(\text { per } \cdot \mathrm{cm}^{2}\right)\end{array}$ & 4040 & 2920 & 2800 & 4640 & 3120 \\
\hline 2 & $\begin{array}{l}\text { Rate of Transpiration } \\
\left(\mathrm{mmol} \mathrm{H}_{2} \mathrm{O} \mathrm{m}^{-2} \cdot \mathrm{s}^{-1}\right)\end{array}$ & 3.05 & 1.56 & 1.63 & 3.02 & 3.74 \\
\hline 3 & $\begin{array}{l}\mathrm{H}_{2} \text { OConductance } \\
\left(\mathrm{mol} \mathrm{H}_{2} \mathrm{O} \mathrm{m}^{-2} \cdot \mathrm{s}^{-1}\right)\end{array}$ & 0.41 & 0.09 & 0.07 & 0.20 & 0.18 \\
\hline
\end{tabular}




\section{Conclusion}

An organism interacts with its ambient environment through exchange of energy and material. A leaf responds to energy and material flow to and from its ambient environment by attaining a certain temperature and a certain rate of transpiration. The temperature of leaf is modified by transpirational cooling due to consumption of latent heat of evaporation. Transpiration effectively plays a significant role in producing cooling by trees in the atmosphere. Moreover, the rate of transpiration is also influenced by the ambient atmospheric temperature. However, different tree species perform differently in cooling process owing to variation in their physical and physiological functioning due to difference in structural and anatomical properties.

\section{Conflicts of Interest}

The authors declare no conflicts of interest regarding the publication of this paper.

\section{References}

[1] Gupta, S.K. (2002) Aspects and Sustainability of Joint Forest Management System. Bishen Singh Mahendra Pal Singh, Dehradun.

[2] Dimoudi, A. and Nikolopoulou, M. (2003) Vegetation in the Urban Environment: Microclimate Analysis and Benefits. Energy and Buildings, 35, 69-76. https://doi.org/10.1016/S0378-7788(02)00081-6

[3] Akbari, H., Dan, K.M., Sarah, B.E. and Hanford, J.W. (1997) Peak Power and Cooling Energy Savings of Shade Trees. Energy and Buildings, 25, 139-148. https://doi.org/10.1016/S0378-7788(96)01003-1

[4] Gates, D.M. (1968) Energy Exchange between Organisms and Environment. In: Lowry, W.P., Ed., Biometeorology: Proc. 28th Ann. Biol.Collog, Oregon State University Press, Corvallis.

[5] Lin, B.-S. and Lin, Y.-J. (2010) Cooling Effect of Shade Trees with Different Characteristics in a Subtropical Urban Park. HortScience, 45, 83-86.

[6] Abdel-Aziz, D.M. (2014) Effects of Tree Shading on Building Energy Consumption. Journal of Architectural Engineering Technology, 3, 135. https://doi.org/10.4172/2168-9717.1000135

[7] Dhyani, P.P. and Purohit, A.N. (1988) Physiology of Ougeinia dalbergiodes Benth. and Its Natural Morphological Variant III Water Vapour Transfer and Energy Exchange Characteristics. The International Tree Crops Journal, 5, 85-95. https://doi.org/10.1080/01435698.1988.9752841

[8] Gates, D.M. (1980) Biophysical Ecology. Springer-Verlag, New York. https://doi.org/10.1007/978-1-4612-6024-0

[9] Kramer, P.J. and Boyer, J.S. (1995) Water Relations of Plants and Soils. Academic, San Diego, CA.

[10] Larcher, W. (1995) Physiological Plant Ecology: Ecophysiology and Stress of Function Groups. Springer Verlag, Berlin. https://doi.org/10.1007/978-3-642-87851-0

[11] Tyree, M.T. (1971) The Steady State Thermodynamics of Translocation in Plants. In: Zimmermann, M.H. and Brown, C.L., Eds., Trees Structure and Function, Sprnger-Verlag, New York, 281-305. https://doi.org/10.1007/978-3-642-88528-0_6 
[12] Srivastava, R.K. and Singh, D. (2003) Forest Fire, Haze Pollution and Climate Change. Indian Forester, 129, 725-734.

[13] Mishra, D. (2011) Working Plan of Forest Research Institute Estate 2011-2020.

[14] Gupta, S.K. and Singh, H. (2017) Observations on Sporadic Flowering in Ficus benjamina L. and Peltophorum africanum L. in New Forest. Indian Forester, 143, 290-291.

[15] Goulden, M.L., Miller, S.D. and da Rocha, H.R. (2006) Nocturnal Cold Air Drainage and Pooling in a Tropical Forest. Journal Geophysical Research, 111, D8. https://doi.org/10.1029/2005JD006037

[16] Mahrt, L., Vickers, D., Nakamura, R., Soler, M.R., Sun, J., Burns, S. and Lenschow, D.H. (2001) Shallow Drainage Flows. Boundary-Layer Meteorology, 101, 243-260. https://doi.org/10.1023/A:1019273314378

[17] Stephen, R.H., Ralf, T., Marion, P., Edgar, C.T., Reuben, N. and Robert, M.E. (2015) The Relationship between Leaf Area Index and Microclimate in Tropical Forest and Oil Palm Plantation: Forest Disturbance Drives Changes in Microclimate. Agricultural Meteorology, 201, 187-195. https://doi.org/10.1016/j.agrformet.2014.11.010

[18] Pessarakli, M. (2005) Handbook of Photosynthesis. 2nd Edition, Taylor \& Francis Group, London, New York, Singapore. https://doi.org/10.1201/9781420027877

[19] Munne-Bosch, S., Nogues, S. and Alegre, L. (1999) Diurnal Variations of Photosynthesis and Dew Absorption by Leaves in Two Shrubs Growing in Mediterranean Field Conditions. New Phytologist, 144, 109-119. https://doi.org/10.1046/j.1469-8137.1999.00490.x

[20] Abeyratne, V.D.K. and Ileperuma, O.A. (2006) Impact of Ambient Air Pollutants on the Stomatal Aperture of Argyreia populifolia. Ceylon. Journal of Science (Biological Science), 35, 9-15.

[21] Esau, K. (1969) Anatomy of Seed Plants. Wiley Eastern Private Limited, New Delhi.

[22] Kramer, P.J. and Kozlowski, T.T. (1960) Physiology of Trees. McGraw-Hill Book Co. Inc., New York.

[23] Noggle, G.R. and George, J.F. (1991) Introductory Plant Physiology. Prentice-Hall, Inc., Englewood Cliffs.

[24] Zimmermann, M.H. and Tyree, M.T. (2002) Zylem Structure and the Ascent of Sap. Springer, New York.

[25] Bonan, G. (2008) Ecological Climatology. 2nd Edition, Cambridge University Press, Cambridge. https://doi.org/10.1017/CBO9780511805530

[26] Amanda, J.C., Deirdre, H.M., Alistair, M.H. and Keara, A.F. (2012) High Temperature Exposure Increases Plant Cooling Capacity. Plant Cell Environment, 22, 396-397.

[27] Collatz, G.J., Ball, J.T., Grivet, C. and Berry, J.A. (1991) Physiological and Environmental Regulation of Stomatal Conductance, Photosynthesis and Transpiration: A Model That Includes a Laminar Boundary Layer. Agriculture and Forest Meteorology, 54, 107-136. https://doi.org/10.1016/0168-1923(91)90002-8

[28] Vile, D., Pervent, M., Belluau, M., Vasseur, F., Bresson, J., Muller, B., Granier, C. and Simonneau, T. (2012) Arabidopsis Growth under Prolonged High Temperature and Water Deficit: Independent or Interactive Effects. Plant Cell Environment, 35, 702-718. https://doi.org/10.1111/j.1365-3040.2011.02445.x

[29] Andersson, N.E., Hertz, C.H. and Rufelt, H. (1954) A New Fast Recording Hygrometer for Plant Transpiration Measurements. Physiological Plantarum, 7, 753. https://doi.org/10.1111/j.1399-3054.1954.tb07736.x

[30] Purohit, A.N. and Dhyani, P.P. (1987) $\mathrm{CO}_{2}$ Exchange under Varying Light Intensi- 
ties in Some under- and Overtemperature Subtropical Tree Species. Photosynthesis Research, 14, 81-88. https://doi.org/10.1007/BF00019594

[31] Jarvis, P.G. (1975) Water Transfer in Plants. In: de Vries, D.A. and Afgan, N.H., Eds., Heat and Mass Transfer in the Biosphere, Vol. 1, Scripta, Washington DC, 369-394.

[32] Holmgren, P., Jarvis, P.G. and Jarvis, M.S. (1965) Resistance to Carbon Dioxide and Water Vapour Transfer in Leaves of Different Plant Species. Physiological Plantarum, 18, 557-573. https://doi.org/10.1111/j.1399-3054.1965.tb06917.x

[33] Goatley, J.L. and Lewis, R.W. (1966) Composition of Guttation Liquid from Rye, Wheat and Barley Seedlings. Plant Physiology, 41, 373-375.

https://doi.org/10.1104/pp.41.3.373 